\title{
PENERAPAN MODEL PEMBELAJARAN SNOWBALL THROWING UNTUK MENINGKATKAN KEMAMPUAN PEMAHAMAN MATEMATIS SISWA
}

\author{
Siti Fitriyani Sartika ${ }^{1}$, Ana Setiani ${ }^{2}$, Novi Andri Nurcahyono ${ }^{3}$ \\ Universitas Muhammadiyah Sukabumi ${ }^{1,2,3}$ \\ pos-el : sitifitriyanisartika@gmail.com ${ }^{1}$, ana.setiani.math@gmail.com², \\ nanurcahyono@gmail.com ${ }^{3}$
}

\begin{abstract}
ABSTRAK
Penelitian ini bertujuan untuk mengetahui adanya perbedaan kemampuan pemahaman matematis siswa dengan model pembelajaran snowball throwing dan model pembelajaran langsung, dan untuk mengetahui apakah model pembelajaran snowball throwing dapat meningkatkan pemahaman matematis siswa. Metode yang digunakan dalam penelitian ini adalah kuasi eksperimen. Populasi dari penelitian ini yaitu siswa kelas VIII MTs-Al-Musthofa. Sampel berjumlah 60 orang yang diambil dengan teknik random sampling. Instrumen pada penelitian ini berupa tes kemampuan pemahaman matematis yang terdiri dari 5 butir soal essay. Hasil penelitian menunjukkan bahwa: 1) kemampuan pemahaman matematis siswa yang menggunakan model pembelajaran snowball throwing lebih baik dibandingkan dengan model pembelajaran secara langsung. 2) Terdapat peningkatan kemampuan pemahaman matematis siswa yang menggunakan model pembelajaran snowball throwing.
\end{abstract}

Kata kunci : snowball throwing, kemampuan pemahaman matematis

\section{ABSTRACT}

This study was aims to determine the differences in students mathematical understanding abilities with using snowball throwing learning model compared to direct learning model, and to determine the effect of snowball throwing learning model on improving students' mathematical understanding abilities. This study used a quasi-experimental method. The population used in this study was class VIII students of MTs-Al-Musthofa with a total sample 60 people taken by random sampling technique. The instrument that used in this research is test instrument mathematical comprehension ability consisting of 5 items essays. The results of the study showed that: 1) the ability of students' mathematical understanding using the snowball throwing learning model was better than the direct learning model. 2) There was an increase in the students' mathematical understanding ability using the snowball throwing learning model.

Keywords : snowball throwing, mathematical understanding ability

\section{PENDAHULUAN}

Matematika merupakan salah satu mata pelajaran yang memegang peranan penting pada ilmu pendidikan dan teknologi. Matematika tidak hanya digunakan untuk berhitung bahkan dalam bidang ekonomi dan bisnis matematika itu sangat penting. Salah satunya untuk memecahkan masalah dengan metode kuantitatif, bahkan matematika merupakan salah satu alat yang digunakan dalam mengembangkan ilmu ekonomi, ilmu pendidikan, ilmu bisnis, ilmu teknologi dan lainnya.

Pendidikan nasional pada saat ini tengah menggalakkan karakter bangsa dan pendidikan budaya yang mendasari nilai-nilai suatu kebajikan sehingga 
menjadi suatu kepribadian warga negara. Bagi siswa mata pelajaran yang dianggap paling sulit itu salah satunya adalah matematika. Maka sebelum siswa mempelajari matematika banyak siswa sudah merasa malas dan tidak suka mempelajari matematika. Kurang efektifnya penyampaian materi kepada siswa merupakan salah satu alasan siswa malas mempelajari matematika.

Berdasarkan hasil observasi dan hasil wawancara dengan salah satu guru matematika di Mts AL-Musthofa pada tanggal 15 januari 2019, bahwa ketika mengajar matematika masih menggunakan metode ceramah sehingga siswa lebih terkesan pasif, dan ketika mata pelajaran berlangsung siswa enggan untuk bertanya dari mana asal rumus itu sehingga siswa hanya menerima dan pemahaman siswa relatif masih rendah. Keadaan ini di dukung oleh hasil nilai rapor pada mata pelajaran matematika kelas VIII di Mts Al-Musthofa dari jumlah keseluruhan 149 siswa, masih sedikit diantaranya nilai yang memenuhi Kriteria Ketuntasan Minimum (KKM). Pada satu tahun terakhir di Mts Al-Musthofa matematika merupakan satu mata pelajaran yang rata-rata nilai akhir semester masih di bawah nilai Kriteria Ketuntasan Minimum (KKM).

Rendahnya perolehan hasil belajar siswa Mts Al-Musthofa di sebabkan oleh banyak faktor salah satunya yaitu jika guru tidak pernah melaksanakan pembelajaran yang inovatif sehingga guru hanya ceramah di depan kelas dan siswa hanya melihat dan mendengarkan dari tempat duduk masing-masing sehingga siswa menjadi terkesan pasif dan sebagian siswa tidak memahami materi yang di sampaikan oleh guru.
Maka dalam proses pembelajaran guru matematika dapat mengelola pembelajaran matematika yang mengembangkan nilai-nilai budaya dan karakter bangsa, misalnya sikap jujur, rasa ingin tahu, kreatif, inovatif, ulet, tekun, percaya diri, pantang menyerah, bertanggung jawab, dan teguh dalam pendirian. Untuk itu, prasyarat yang harus dimiliki seorang guru matematika tentu adalah penerapan nilai-nilai itu terlebih dahulu dan pola sikap, pola tutur, dan pola tingkah laku dari guru itu sendiri. Atinya, guru perlu menjadi teladan terlebih dahulu bagi peserta didiknya.

Sehingga salah satu cara yang dapat menyelesaikan faktor-faktor tersebut yaitu dari proses pembelajaran. Nurcahyono (2015) mengatakan bahwa tugas profesional seorang guru yaitu menjadikan pelajaran yang sebelumnya tidak menarik menjadi menarik, yang sebelumnya dirasakan sulit menjadi mudah, yang sebelumnya tidak berarti menjadi bermakna. Pendapat tersebut diperkuat oleh Yamin (2007: 90) yang mengemukakan bahwa melempar bola pertanyaan atau Snowball Throwing merupakan salah satu strategi yang berfungsi merangsang siswa untuk mengajukan pertanyaan dalam kegiatan pembelajaran.

Dalam penelitian Yuli (2015) mengatakan bahwa dengan melakukan metode pembelajaran kooperatif model snowball throwing lebih efektif daripada model pembelajaran konvensional terhadap hasil belajar matematika siswa kelas VII SMP N 11 Yogyakarta tahun pelajaran 2013/2014. Snowball Throwing adalah suatu permainan melempar bola salju sebagai salah satu strategi pembelajaran yang 
dapat merangsang siswa untuk mengajukan pertanyaan dan menjawab pertanyaan (Sholeh, 2012: 230)

Adapun rumusan masalah dalam penelitian ini adalah :

1. Apakah kemampuan pemahaman matematis siswa dengan model pembelajaran snowball throwing lebih baik dari model pembelajaran konvensional?

2. Apakah model pembelajaran snowball throwing dapat meningkatkan pemahaman matematis siswa?

Berdasarkan rumusan masalah penelitian ini bertujuan untuk :

a. Mengetahui adanya perbedaan kemampuan pemahaman matematis siswa dengan model pembelajaran snowball throwing dan model pembelajaran langsung.

b. Mengetahui apakah model pembelajaran snowball throwing dapat meningkatkan pemahaman matematis siswa .

Sedangkan hipotesis dalam penelitian ini sebagai berikut :

1) Kemampuan pemahaman matematis siswa dengan model pembelajaran snowball throwing lebih baik dari model pembelajaran konvensional.

2) Terdapat peningkatan kemampuan pemahaman matematis siswa dengan model pembelajaran snowball throwing.

\section{METODE PENELITIAN}

Untuk penelitian ini metode yang digunakan yaitu metode kuantitatif dan menggunakan metode penelitian Quasi Experimental Design atau eksperimen semu karena dalam penelitian ini peneliti ingin menerapkan suatu model pembelajaran snowball throwing untuk meningkatkan kemampuan pemahaman matematis siswa.

Sesuai dengan yang di kemukakan oleh Sugiyono (2016: 77) kuasi eksperimen adalah penelitian semu yang tidak di lakukan kontrol pada semua variabel yang mempengaruhi kecuali variabel yang di teliti. Variabel yang di teliti tersebut meliputi variabel bebas dan terikat. Penelitian ini bertujuan untuk melihat hasil dari penerapan variabel bebas terhadap variabel terikat.

Dalam penelitian ini peneliti menggunakan desain penelitian pretest-posttest-only control design. Penelitian ini dilakukan di Mts AlMusthofa Kecamatan Cirenghas, Kabupaten Sukabumi Tahun Pelajaran 2019/2020. Dalam menentukan sampel, peneliti menggunakan teknik simple random sampling karena pengambilan anggota sampel dari populasi di lakukan secara acak tanpa memperhatikan strata yang ada dalam populasi itu.

Teknik pengumpulan data yang digunakan dalam penelitian ini yaitu lembar validasi tes berupa angket dan tes tertulis yang berbentuk essai untuk mengetahui kemampuan pemahaman matematis siswa setelah menggunakan model pembelajaran snowball throwing serta dokumentasi.

Teknis analisis data yang digunakan yaitu :

1) Uji t dua sampel tidak berpasangan untuk membandingkan hasil posttest kemampuan pemahaman matematis siswa yang menggunakan model pembelajaran snowball throwing dan model pembelajaran konvensional.

2) Uji N-Gain untuk mengetahui apakah ada peningkatan 
kemampuan pemahaman matematis siswa dengan menggunakan model pembelajaran snowball throwing dan model pembelajaran secara langsung. Untuk menghitung NGain dapat digunakan rumus Hake (Archambault, 2008):

$\mathrm{N}-$ Gain $=\frac{S_{\text {post }}-S_{\text {pre }}}{S_{\text {maks }}-S_{\text {pre }}}$

Keterangan :

$\mathrm{S}_{\text {post }}=$ skor posttest

$S_{\text {pre }}=$ skor pretest

$\mathrm{S}_{\text {maks }}=$ skor maksimum ideal

Kriteria skor N-Gain dapat dilihat pada tabel berikut:

Tabel 1. Kategori Perolehan Skor N-Gain

\begin{tabular}{|c|c|}
\hline Batasan & Kategori \\
\hline $\mathrm{g}>0,7$ & Tinggi \\
\hline $0,3<\mathrm{g} \leq 0,7$ & Sedang \\
\hline $\mathrm{g} \leq 0,3$ & Rendah \\
\hline
\end{tabular}

\section{HASIL DAN PEMBAHASAN}

Data tentang kemampuan awal pemahaman matematis siswa diperoleh dari hasil pre-test kelas VIII.1 dan VIII.4 Mts.Al-Musthofa Kabupaten Sukabumi Tahun Ajaran 2019/2020. Data awal ini digunakan untuk mengetahui keseimbangan awal kemampuan pemahaman matematis siswa diantara kedua kelas yaitu VIII.1 dan VIII.4. Berikut rangkuman deskripsi tentang data kemampuan awal siswa.

Tabel 2. Deskripsi Data Kemampuan Awal Pemahaman Matematis Siswa

\begin{tabular}{|c|c|c|}
\hline Kelas & Rerata & $\begin{array}{c}\text { Nilai } \\
\text { Maksimum }\end{array}$ \\
\hline Eksperimen & 6,033 & 14 \\
\hline Kontrol & 6,567 & 14 \\
\hline
\end{tabular}

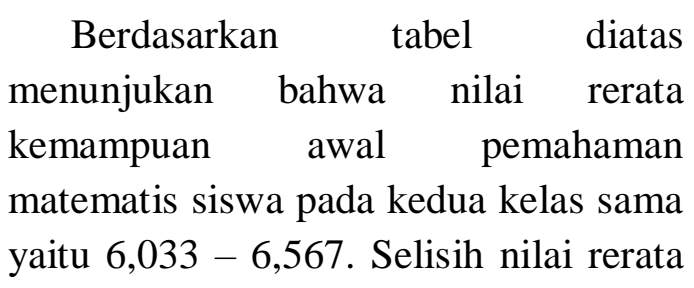

kedua kelas tersebut yaitu 0,534 ini menunjukan nilai rerata kedua kelas yaitu 6,3. Untuk mengetahui keseimbangan kemampuan awal pemahaman matematis siswa perlu dilakukan uji keseimbangan kemampuan awal. Sebelum melakukan uji keseimbangan kemampuan awal siswa, terlebih dahulu dilakukan uji prasyarat yang dijabarkan sebagai berikut :

1. Uji Prasyarat

Uji prasyarat analisis digunakan untuk melihat apakah kemampuan awal pemahaman matematis siswa seimbang. Uji prasyarat mencakup uji normalitas dan uji homogenitas data kemampuan awal siswa (pre-test).

a) Uji Normalitas

Sebelum dilakukan uji hipotesis diperlukan uji prasyarat yang terdiri dari uji normalitas dan uji homogenitas. Uji normalitas digunakan untuk melihat apakah data berasal dari populasi yang berdistribusi normal. Uji normalitas yang digunakan pada pada penelitian ini yaitu liliefors dengan taraf signifikan $(\alpha) \quad 0,05$. Berikut ini rangkuman hasil uji normalitas pada kemampuan awal pemahaman matematis siswa.

Tabel. 3. Rangkuman Hasil Uji Normalitas Kemampuan Awal Siswa

\begin{tabular}{|c|c|c|c|}
\hline Kelas & $\mathrm{L}_{\text {maks }}$ & $\mathrm{L}_{\text {tabel }}$ & Keputusan \\
\hline Eksperimen & 0,153 & 0,161 & $\mathrm{H}_{0}$ diterima \\
\hline Kontrol & 0,137 & 0,161 & $\mathrm{H}_{0}$ diterima \\
\hline
\end{tabular}

Berdasarkan hasil rangkuman uji normalitas pada kemampuan awal pemahaman matematis siswa menunjukan bahwa untuk kelas eksperimen diperoleh $\mathrm{L}_{\text {maks }}=0,153$ dan untuk kelas kontrol diperoleh $\mathrm{L}_{\text {maks }}=0,137$. Ini memperlihatkan 
bahwa $\mathrm{L}_{\text {hitung }}<\mathrm{L}_{\text {tabel }}$ sehingga dapat disimpulkan kedua sampel berasal dari populasi yang berdistribusi normal.

b) Uji Homogenitas

Uji homogenitas dilakukan untuk mengetahui data kemampuan awal kelas eksperimen dan kelas kontrol mempunyai variansi yang sama atau tidak. Jika data mempunyai variansi yang sama maka kelompok tersebut dikatakan homogen. Berikut rangkuman hasil uji homogenitas.

Tabel 4. Rangkuman Hasil Uji

Homogenitas Pada Data Pre-test

\begin{tabular}{|c|c|c|c|}
\hline Kelas & $\mathrm{X}_{\text {tabel }}$ & $\mathrm{X}_{\text {hitung }}$ & Keputusan \\
\hline $\begin{array}{c}\text { Eksperimen } \\
\text { Kontrol }\end{array}$ & 0,934 & 0,999 & $\begin{array}{c}\mathrm{H}_{0} \\
\text { diterima }\end{array}$ \\
\hline
\end{tabular}

Berdasarkan tabel diatas bahwa $\mathrm{DK}=\{\mathrm{b} \mid \mathrm{b}<0.9348\}$ dikarenakan nilai b hitung yaitu 0,9999 berada di daerah $\mathrm{H}_{0}$, maka $\mathrm{H}_{0}$ diterima dan data pretest dari kedua sampel tersebut memiliki varians yang sama.

c) Uji keseimbangan

Uji keseimbangan rata-rata kemampuan awal siswa untuk mengetahui bahwa kedua sampel mempunyai kondisi awal yang sama dan seimbang. Uji keseimbangan yang digunakan adalah uji $t$ dua pihak. Berikut rangkuman hasil uji data keseimbangan siswa.

Tabel 5. Rangkuman Hasil Uji

Keseimbangan Rata-Rata Awal

\begin{tabular}{|c|c|c|c|}
\hline Sampel & $\mathrm{t}_{\text {hitung }}$ & $\mathrm{t}_{\text {tabel }}$ & Keputusan \\
\hline $\begin{array}{c}\text { Kelas Eksperimen } \\
\text { Kelas kontrol }\end{array}$ & $-0,291$ & 3,466 & $\mathrm{H}_{0}$ diterima \\
\hline
\end{tabular}

Berdasarkan tabel diatas bahwa $\mathrm{t}_{\text {hitung }}<\mathrm{t}_{\text {tabel }}$ sehingga data hasil pretest kelas eksperimen dan kelas kontrol memiliki kemampuan pemahaman matematis yang sama atau tidak ada perbedaan antara kelas kontrol dan eksperimen.
Deskripsi data akhir siswa ini di dapatkan dari hasil postest. Data postest digunakan untuk mengetahui apakah kemampuan pemahaman matematis siswa sama atau tidak antar kelas eksperimen dan kelas kontrol setelah diterapkan model pembelajaran kooperatif tipe snowball throwing. Analisis data postest terdiri dari uji normalitas, uji homogenitas, dan uji $\mathrm{t}$ dua sampel. Data yang diperoleh dari hasil pengukuran dianalisis untuk mengetahui apakah penerapan model pembelajaran snowball throwing pada kemampuan pemahaman matematis siswa dapat dilihat dari tabel berikut.

Tabel 6. Hasil Postest

\begin{tabular}{|c|c|}
\hline Kelas & Postest \\
\hline Eksperimen & 16,133 \\
\hline Kontrol & 9,567 \\
\hline
\end{tabular}

Berdasarkan hasil postest pada kelas eksperimen lebih besar yaitu 16,133 dibandingkan hasil postest kelas kontrol lebih rendah yaitu 9,567. Adapun langkah-langkah yang digunakan untuk menganalisis data postest sebagai berikut :

a) Uji Normalitas

Sebelum dilakukan uji hipotesis diperlukan uji prasyarat yang terdiri dari uji normalitas dan uji homogenitas. Uji normalitas digunakan untuk melihat apakah data berasal dari populasi yang berdistribusi normal. Uji normalitas yang digunakan pada penelitian ini yaitu liliefors dengan taraf signifikan (a) 0,05. Berikut ini rangkuman hasil uji normalitas pada kemampuan pemahaman matematis siswa.

Tabel 7. Hasil Uji Normalitas Data Postest

\begin{tabular}{|c|c|c|c|}
\hline Kelas & $\mathrm{L}_{\max }$ & $\mathrm{L}_{\text {tabel }}$ & Keterangan \\
\hline Eksperimen & 0,154 & 0,161 & Normal \\
\hline Kontrol & 0,140 & 0,161 & Normal \\
\hline
\end{tabular}


Berdasarkan tabel diatas bahwa data pada kelas eksperimen dan kelas kontrol berdistribusi normal, dikarenakan $\mathrm{L}_{\max }<\mathrm{L}_{\text {tabel }}$.

b) Uji Homogenitas

Uji homegenitas dilakukan untuk mengetahui data akhir kelas sampel mempunyai variansi yang sama atau tidak. Jika data mempunyai variansi yang sama maka kelompok dikatakan homogen. Berikut ini rangkuman hasil uji homogenitas pada kemampuan pemahaman matematis siswa.

Tabel 8. Rangkuman Hasil Uji Homogenitas Data Posttest

\begin{tabular}{|c|c|c|c|}
\hline Kelas & $\mathrm{X}_{\text {tabel }}$ & $\mathrm{X}_{\text {hitung }}$ & Keputusan \\
\hline $\begin{array}{c}\text { Eksperimen } \\
\text { Kontrol }\end{array}$ & 0,9348 & 0,9681 & $\mathrm{H}_{0}$ diterima \\
\hline
\end{tabular}

Berdasarkan tabel diatas bahwa $\mathrm{DK}=\{b \mid \mathrm{b}<0.9348\}$ dikarenakan nilai b hitung yaitu 0,9681 berada di daerah $\mathrm{H}_{0}$, maka $\mathrm{H}_{0}$ diterima dan data posttest dari kedua sampel tersebut memiliki varians yang sama.

2. Uji Hipotesis

Uji hipotesis ini bertujuan untuk mengetahui mana yang lebih baik antara kelas yang menggunakan model pembelajaran snowball throwing dan yang menggunakan pembelajaran langsung. Data posest dianalisis menggunakan uji t. Berdasarkan perhitungan dan analisis, diperoleh hasil pengujian hipotesis sebagai berikut.

Tabel 9. Rangkuman Hasil Uji t

\begin{tabular}{|c|c|c|c|}
\hline Kelas & $\mathrm{t}_{\text {hitung }}$ & $\mathrm{t}_{\text {tabel }}$ & Keputusan \\
\hline $\begin{array}{c}\text { Eksperimen } \\
\text { Kontrol }\end{array}$ & 3,715 & 3,466 & $\mathrm{H}_{0}$ ditolak \\
\hline
\end{tabular}

Berdasarkan tabel diatas bahwa $t_{\text {hitung }}>t_{\text {tabel }}$ sehingga $\mathrm{H}_{0}$ ditolak atau artinya $\mathrm{H}_{1}$ diterima, sehingga hasil posttest pada kedua kelompok tersebut menyatakan bahwa kelompok yang menggunakan model pembelajaran snowball throwing lebih baik dibandingkan dengan kelompok yang menggunakan model pembelajaran langsung.

3. Uji N-Gain

Uji N-gain bertujuan untuk mengetahui apakah ada peningkatan terhadap kemampuan pemahaman matematis siswa yang diberi model pembelajaran snowball throwing dan model pembelajaran secara langsung. Berdasarkan perhitungan dan analisis, diperoleh hasil sebagai berikut:

Tabel 10. Rangkuman Hasil Uji N-Gain

\begin{tabular}{|c|c|c|}
\hline Sampel & N-gain & Keterangan \\
\hline Kelas eksperimen & 0,7601 & Tinggi \\
\hline Kelas kontrol & 0,2559 & Rendah \\
\hline
\end{tabular}

Berdasarkan tabel diatas bahwa kelas yang menggunakan model pembelajaran snowball throwing dapat meningkatkan kemampuan pemahaman matematis siswa.

Penggunaan model pembelajaran kooperatif tipe snowball throwing pada pembelajaran matematika merupakan hal yang baru bagi para siswa kelas VIII MTs Al-Musthofa Kabupaten Sukabumi. Penerapan model pembelajaran kooperatif tipe snowball throwing memiliki tahapan-tahapan yang membuat siswa lebih aktif dan lebih dapat mengembangkan kemampuan pemahaman matematis siswa. Kemampuan awal pemahaman matematis siswa berasal dari data yang berdistribusi normal dan kedua kelas tersebut memiliki varians yang sama dan pada kemampuan awal siswa memiliki kemampuan pemahaman matematis yang seimbang.

Pada pertemuan pertama terdapat kesulitan yang dialami siswa yaitu dalam unsur-unsur kubus dan balok terutama dalam menentukan diagonal 
ruang dan bidang diagonal. Pada pertemuan kedua terdapat kesulitan yang dialami siswa yaitu dalam membuat jaring-jaring kubus dan balok dan siswa untuk menentukan panjang diagonal ruang dengan menggunakan phytagoras. Pada pertemuan ketiga terdapat kesulitan yang dialami siswa dalam menentukan luas permukaan kubus dan balok. Pada pertemuan ke empat siswa mengalami kesulitan dalam menentukan volume kubus dan balok. Pada pertemuan ke lima terdapat kesulitan yang dialami siswa yaitu dalam memahami soal cerita. Dalam pembelajaran siswa belajar bersama sebagai satu tim dalam menyelesaikan tugas-tugas kelompok untuk mencapai tujuan bersama, maka dalam pembelajaran ini adanya ketergantungan dalam kelompok.

Berdasarkan hasil analisis data untuk hipotesis tentang perbedaan kemampuan pemahaman matematis siswa yang menggunakan model pembelajaran snowball throwing lebih baik di bandingkan dengan siswa yang menggunakan model pembelajaran langsung menunjukan bahwa kemampuan pemahaman matematis siswa siswa yang menggunakan model pembelajaran snowball throwing lebih baik dibandingkan dengan siswa yang menggunakan model pembelajaran pembelajaran langsung.

Sesuai dalam penelitian Yuli (2015) mengatakan bahwa dengan melakukan metode pembelajaran kooperatif model snowball throwing lebih efektif daripada model pembelajaran konvensional terhadap hasil belajar matematika siswa kelas VII SMP N 11 Yogyakarta tahun pelajaran 2013/2014. Dan untuk hipotesis tentang peningkatan kemampuan pemahaman matematis siswa yang menggunakan model pembelajaran snowball throwing meningkat dibandingkan dengan siswa yang menggunakan model pembelajaran langsung menunjukan bahwa siswa yang menggunakan model pembelajaran snowball throwing kemampuan pemahaman matematis terjadi peningkatan dalam kategori tinggi sedangkan siswa yang menggunakan model pembelajaran langsung terjadi peningkatan dalam kategori rendah.

\section{KESIMPULAN}

Kemampuan pemahaman matematis siswa dengan menggunakan model pembelajaran snowball throwing lebih baik daripada yang menggunakan model pembelajaran langsung. Peningkatan kemampuan pemahaman matematis siswa yang menggunakan model pembelajaran snowball throwing baik daripada yang menggunakan model pembelajaran langsung.

\section{DAFTAR PUSTAKA}

Arcambault, J. (2008). The Effect of Developing Kinematics Concepts Graphically Prior to Introduching Algebraic Problem Solving Techniques. Action Research Reguared for the Master of Natural Science Degree with Concentration in Physics. Arizona State University.

Natawidjaja, dkk. (2007). Rujukan Filsafat, Teori dan Praksis Ilmu Pendidikan. Bandung: UPI Press

Nurcahyono, N. A. (2015). Modifikasi

Model Pembelajaran Kooperatif Tipe TPS dan NHT dengan Pendekatan CTL untuk Meningkatkan Prestasi Belajar Matematika Siswa. Prosiding 
Seminar Nasional Matematika dan Pendidikan Matematika UMS 2015, 134

Sholeh, H. (2012). Metode

Edutainment. Jogjakarta: Diva Press.

Yuli, A. (2015). Efektivitas Model Pembelajaran Snowball Throwing Melalui Pemanfaatan Prized Chart terhadap Hasil Belajar Matematika
Siswa Kelas VII SMP N 11 Yogyakarta. Jurnal Pendidikan Matematika UNION. 2(3), 221-225.

Yamin, M. (2007). Kiat Membelajarkan Siswa. Jakarta: Gaung Persada Press.

Sugiyono, P. D. (2016). Metode Penelitian Kuantitatif, Kualitatif, dan R\&D. Bandung: Alfabeta. 